\title{
Records of the
}

\section{HARLEQUIN DUCK}

\section{in Manitoba and Adjacent Regions}

\author{
by MARTIN K. McNICHOLL*
}

Between 8:00 and 9:00 a.m., C.D.T., on October 5, 1963, two veteran Manitoba birdwatchers, William ("Bill") Adams and Perry Silverman (both now deceased), spotted a small diving duck in the fast flowing waters of the Assiniboine River immediately west of the footbridge crossing the river in Assiniboine Park, Winnipeg. After closely scrutinizing the bird, they concluded it was a female Harlequin Duck, the first Winnipeg record. The observation was verified a few minutes later by Herbert W. R. Copland, Andrew Heidrick, Harold V. Hosford, Peggy Lawson, the writer, and several others. As noted by Harold Hosford: "At rest, the bird appeared as a dull brown bird with three white spots on the head, one in front of the eyes, one in the auricular region and another larger one below the eyes. In flight there was a complete lack of any pattern on the body or wings." 12 These are characteristic features of the female Harlequin, as reported by most field guides. ${ }^{26}$ In addition, the duck was in "fast water" and occasionally scrambled up on the rocks, habitat and behaviour typical of the species. ${ }^{20} 167$ The bird was seen again the following day by Peggy Lawson, but could not be located on October 7 by the writer and Ken Johannesson.

As the Harlequin Duck is a "rare transient" for Manitoba, a review of Manitoba records seemed worth while. ${ }^{10}$ The earliest Manitoba record was a bird cited by E. A. Preble and several other authors as having been "examined" prior to 1863 by Blakiston at York Factory. ${ }^{28}$ Unfortunately, this record must

* Department of Zoology,

University of Alberta,

Edmonton, Alberta T6G 2El. be regarded as hypothetical, as $t$ precise locality where the bird was o tained is not clear. Preble also not two early Hudson Bay and James B records, to which T. H. Manning 0 fered no additions. ${ }^{18}$ The preci locality of neither record is known However, there are recent sight recor of single males at Churchill from Ju 11 to 14,1970 and on June 2 1971.279 In southern and centr Manitoba, the first probable record w of three "brilliantly coloured litt ducks" shot by Fred Ward at Shoal La in the spring of 1898 and identifi several years later as Harlequins Charles Holden reportedly had a $\mathrm{m}$ : shot "many years ago" on La Manitoba about 1910.1719 Another w observed by Kenneth Holden at Porta Creek in 1928.19 Twenty-two ye: later, on September 15, 1950, Lazan Partridge shot two immatures at $\mathrm{Pi}$ Lake, Big Eddy, north of The Pas, at took them to Sam Waller for ide tification. ${ }^{23}$ One of these remains Waller's Little Northern Museum at T Pas and the other is a study skin at $t$ Manitoba Museum of Man and Natu (R. W. Nero, pers. comm.). ${ }^{34}$ The ne record was of a male near Ponemah Lake Winnipeg on June 4, 1961, w detailed observations made by $\mathrm{Pel}$ Silverman. ${ }^{19}$ A sight observati without details by Mrs. E. R. Pogue one bird is available for Bagot in ea June, 1969. ${ }^{21}$

Thus there are 10 records of this du for Manitoba (Fig. 1). Of these, four $i$ volve specimens, although one of thi may have been taken outside $t$ province, and the identification Ward's birds was not made while specimens were available. Of the sight records, four (for Winnipeg, $t$ two Churchill records, and Silverma 
revious record) are all "acceptable," as he details are well documented, or the bservation was confirmed by several cople in each case. No details are nown for the other two sight records. hus, the Harlequin Duck is a rare becies in Manitoba.

In Canada, the Harlequin Duck reeds in two widely separated areas: a estern population in Yukon, British olumbia and the Rocky Mountains of buthern Alberta, with additional sumter records in Mackenzie: and an istern population on southeastern Bafn Island, Labrador, parts of Quebec, nd possibly Newfoundland." ligration is from these areas to the basts. Although the Harlequin breeds Rocky Mountain portions of Alberta.

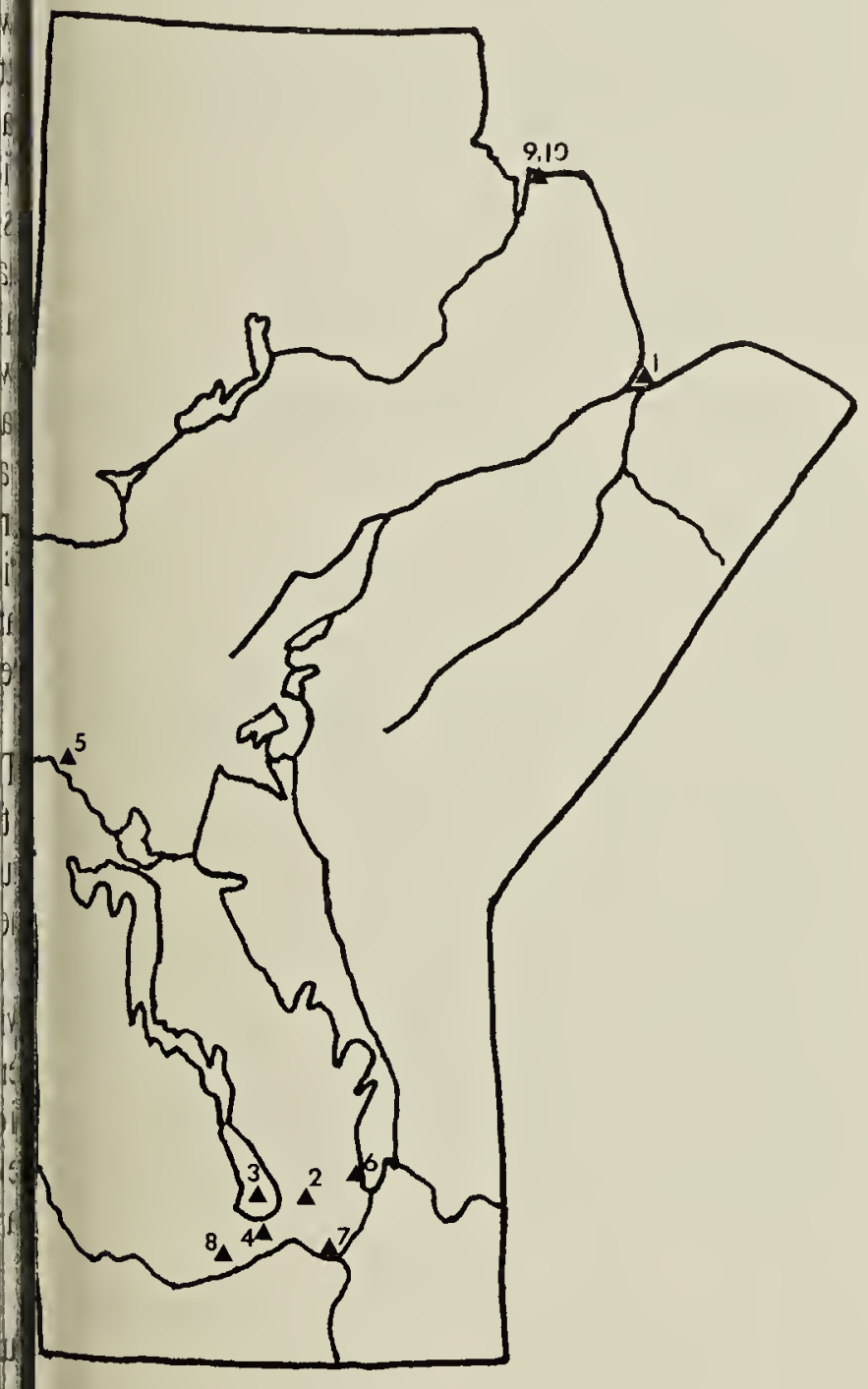

gure 1. Locations of Manitoba records of the Harlequin Duck (numbered chronologically). 1. York Factory; 2. Shoal Lake (sometimes divided into three lakes); 3. Lake Manitoba; 4. Portage Creek (Delta area); 5. Big Eddy (Pike Lake); 6. Ponemah; 7. Winnipeg; 8. Bagot; 9. and 10. Churchill.
There are few prairie records. ${ }^{(10}$ It is very rare in Alberta away from the mountains, with records at Cooking Lake, Beaverhill Lake, and Lake Athabasca. 10 30 In Saskatchewan, "several pairs" were reported seen at Saskatchewan Landing, north of Swift Current on May 31, 1934. ${ }^{15}$ A male was shot by "one of Dick Hamilton's boys" at that time, and mounted by George Warren. ${ }^{1.5}$ Another reported for 1966 by M. M. Tremaine has not been included in subsequent reports, because of lack of details (M. Belcher, pers. comm.). ${ }^{3: 3}$ However, Dr. Tremaine, who is familiar with the species, took convincing details which she kindly sent me (pers. comm., 1968). The bird was a female seen on the Puskwakau River $\left(54^{\circ} 34^{\prime} \mathrm{N}, 103^{\circ}\right.$ $34^{\prime}$ 'W) on July 13 and 14, 1966. Details noted included the three white spots (of which the top spot was fairly indistinct), the lack of white in the wing, and the dark colouration (similar to that of a female Surf Scoter). In 1968 three presumed males in eclipse were seen in Wascana Marsh, Regina on September 6 , and additional sightings were made by several competent observers north of Regina on October 10, 22 and 23." Another male was observed and photographed by several observers in the Regina area from June 5 to 13 , 1971.313

There are also very few North Dakota records. The first record for the state was a specimen taken at Mandan about September 23, 1912, ${ }^{24}$ and there have been sight records since, the most recent being a female seen at Valley City on October 5, 1971.14

To the east, the Harlequin may be increasing as a migrant or wintering bird. It has been considered very rare in Ontario in the past and even more recently. ${ }^{31}{ }^{2} 28$ 11 However, there have been several recent records, prompting C. E. Goodwin to comment, "this is yet another species which is becoming increasingly regular on the lower Great Lakes." Although most Ontario records are from eastern areas, there are records from Port Arthur (now Thunder Bay) as early as the late 1880's, and from the Atikokan area on May 16 , 1963.' 2.5 In Minnesota, T. S. Roberts had relegated it to the hypothetical list, 
but added it to the state list as he went to press on the basis of an immature male shot on April 10, 1932. ${ }^{29} 4$ By 1966 there were 14 records, and several have appeared in Audubon Field Notes, American Birds, and The Loon since."

I would like to thank Miss Margaret Belcher and Dr. Mary Tremaine for information they supplied for this note, Herbert W. R. Copland for a copy of the Lawrence reference, and Dr. Robert W. Nero for reading the manuscript.

'ATKINSON, G. E. 1894. A suminer's collecting and observations at Port Arthur, Ontario. Biol. Review of Ontario 1: 94-101.

${ }^{2}$ BERNARD, R. F. (editor). 1966. Fall migration. August 16 - Novernber 30, 1965. Western Great Lake region. Audubon Field Notes 20: 45-46, 50-53.

'BR AZIER, F. H. 1971. Harlequin Duck at Regina. Blue Jay 29: 128-129.

${ }^{4}$ BRECKENRIDGE, W. J. 1932. The Harlequin Duck in Minnesota. Auk 49: 345.

BRUNTON, D. F. 1968. The Harlequin Duck in Saskatchewan. Blue Jay 26: 178-179.

"COWAN, I. McT. 1955. Birds of Jasper National Park, Alberta, Canada. Can. Dept. Northern Affairs and Nat. Res. Wildl. Mgmt. Bull. Series 2. No. 8.

'DELACOUR, J. 1959. The waterfowl of the World. Vol. 3. Country Life Ltd., London.

${ }^{\text {} F L E M I N G, ~ J . ~ H . ~ 1930 . ~ O n t a r i o ~ b i r d ~ n o t e s . ~ A u k ~}$ 47: 64.71 .

"FORSTER, R. A. 1972. Winter Wren, Sprague's Pipit and other records at Churchill. Blue Jay 30: 27-28.

"GODFREY, W. E. 1966. The birds of Canada. Nat. Mus. Can. Bull. No. 203, Biol. Ser. No. 73 , Ottawa.

"GOODWIN, C. E. (editor). 1972. The fall migration. August 16, 1971 to November 30 , 1971. Ontario. American Birds 26: 54-59.

${ }^{12}$ HOSFORD, H. 1963. Stragglers. Nat. Hist. Soc. of Manitoba Newsletter No. 6: 58.

${ }^{1: 3 O U S T O N, C . ~ S . ~(e d i t o r) . ~ 1971 . ~ T h e ~ n e s t i n g ~}$ season. June 1, 1971 to August 15, 1971. Northern Great Plains region. American Birds 25: 869-872.
${ }^{1}$ HOUSTON, C. S. (editor). 1972. The fat migration. August 16, 1971 to November 3 1971. Northern Great Plains. American Birds 26 78-80.

${ }^{1.5}$ HOUSTON, C. S., F. G. BARD, and R. W NERO. 1958. Further information on certai unusual Saskatchewan bird records. Blue Jay 16 64-65

1"KORTRIGHT, F. H. 1942. The ducks, geese an swans of North America. Stackpole Co Harrisburg and Wildl. Mgmt. Inst., Washington

${ }^{17}$ LAWRENCE, A. G. 1928. Harlequin Duch Chickadee Notes. No. 392. Winnipeg Free Pres September 27, 1928.

"MANNING, T. H. 1952. Birds of the west Jam Bay and southern Hudson Bay coasts. Nat. Mu Can. Bull. No. 125.

${ }^{19}$ MOSSOP, H. 1961. Rare clown of a duck Chickadee Notes. No. 335. Winnipeg Free Pres June 24, 1961 .

"MOSSOP, H. 1963. A rare visitor. Chickade Notes. No. 456. Winnipeg Free Press, Octobe $12,1963$.

${ }^{21}$ MOSSOP, H. 1969. (Untitled). Chickadee Note No. 766. Winnipeg Free Press, October 25, 196 ${ }^{2} \mathrm{NASH}, \mathrm{C} . \mathrm{W} .1905$. Checklist of the vertebrates Ontario and catalogue of specimens in th biological section of the Provincial Museum Birds. Dept. of Education, Toronto.

${ }^{2}$ NORRIS-ELYE, L. T. S. 1951. Manitoba bir records, 1950. Can. Field-Nat. 65: 79-80.

${ }^{24} \mathrm{OBER}$ HOLSER, H. C. 1919 . Histrionicu histrionicus pacificus in North Dakota. Wilso Bull. 31: 26.

2.PER UNIAK, S. 1969. The birds of the Atikoka area, Rainy River district, Ontario. Part I. On Field Biol. 23: 35-38.

2TPETER SON, R. T. 1947. A field guide to the bird (second rev. ed.). Houghton Mifflin, Boston.

${ }^{27}$ PITTAWAY, R., and R. W. NERO. 1971. Recer bird notes of interest for Churchill, Manitob Blue Jay 29: 60-63.

${ }^{2 x}$ PREBLE, E. A. 1902. A biological investigation c the Hudson Bay region. North Am. Fauna. No 22.

"ROBERTS, T. S. 1932. The birds of Minnesotc Vol. 1. Univ. of Minnesota Press, Minneapolis.

"SALT, W. R., and A. L. WILK. 1966. The hird of Alberta (second, rev. ed.). Dept. of Industr and Commerce, Edmonton.

"SETON, E. E. T. 1885. Interesting records fror Toronto, Canada. Auk 2: 334-337.

3:TAVERNER, P. A. 1919. The birds of Shod Lake, Maritoba. Ottawa Nat. 32: 137-144; 157 164.

33TREMAINE, M. M. 1966. Saskatchewa revisited. Blue Jay 24: 182-183.

${ }^{3}$ WALLER, S. 1967. Some interesting bird record from The Pas, Manitoba. Blue Jay 25: 120. 